Dr. Hunt shows wide acquaintance with the literature of this subject. He exposes the fallacies of "Science and Health"that singular medley of sense and nonsense, that hotch-potch of scientific and philosophical jargon, with a few grains of truth scattered through it-making its absurdity more visible by setting it in the white light of Biblical truth. He then compares the healings of this cult with those of other sects and cults in various lands and ages, showing how a woman of not very high character has taken the psychological process of suggestion which has been exploited for one purpose or anather and under one pretence or another in all climes and times, and built a "religion" upon it by the sheer power of egotistical self-assertion. It can be explained only by the peculiar susceptibility of many minds in this age of religious disintegration and confusion.

Dr. Hunt has done an effective bit of work in this book. He strikes straight from the shoulder, as his manner is.

C. S. GARdner.

\title{
III.-RELIGION AND MISSIONS.
}

History of Religions. By George Foote Moore, D.D., LL.D., Professor of the History of Religion in Harvard University. I. China Japan Egypt Babylonia Assyria India Persia Greece Rome. New York, 1913: Charles Scribner's Sons. $x i v+637$ pp. $\$ 2.50$ net.

This is the first of two volumes treating this subject in the "International Theological Library." For the second volume are reserved Judaism, Christianity and Mohammedanism. Even so large a volume leaves all too little space for the discussion of so many religions, some of them with so many variant developments. The author is shut up to little more than summary outlines. He has approached his task with the modesty of full scholarship under limitations. It is especially gratifying that speculations about "primitive religion" are not introduced to fill the vacuum of historical ignorance of the earlier stages of any ancient religion. The fundamental nature of religion in the personal constitution of man is recognized. The essential unity of religions in a common religion is also acknowledged. Yet this is 
not a history of religion, but of religions, and the work adheres strictly to the ideal of the plan. What we have, therefore, is a series of objective histories of the religious manifestations in the religions of the various countries named in the title. The unity of the parts is, therefore, of three kinds. First, there is the merely artificial unity of collection in a single volume. Next, there is the inevitable unity of a basal religiousness of which religions are differentiations under varying environments and influences. Chiefly there is the unity of a common view-point and method in dealing with all the religions. The perspective and proportion are good.

The general ethnic facts for each people are given briefly and the earliest historical religious beliefs and practices are outlined. Then we find outlines of the separate religions as separate, with attention to their interaction and relation. This plan is well adapted to each of the fields treated in the volume.

For the most part only praise can be felt for the objective fairness and clearness of the accounts of the various religions. One might think that the influence of the religions on the ethics and general social conditions of the people could have been treated a little more adequately and with possibly a little less charity. In such matters charity ought not to cover too many sins. Some of the latest sects are overlooked occasionally, as in Japan; and again treated so summarily as not to give accurate information, as in case of the Somajes of India.. But one cannot demand everything in a book of such limitations. It is cause for gratitude that students of religions are to have these two volumes by Professor Moore.

W. O. Carver.

The Three Religions of China. Lectures delivered at Oxford. . By the Rev. W. E. Soothill, M.A., F. R. G. S. (Late Principal of the Shansi Imperial University, President designate of the United Universities, proposed Central-China University). Hodder \& Stoughton; London; George H. Doran Company, New York, 1913. xii-ł-324 pages. $\$ 1.50$ net.

Mr. Soothill has spent many years in fruitful study and service in China. He is a translator and compiler in both Chinese 